\title{
PENGARUH KUAT ARUS LISTRIK DC PADA SELENOID TERHADAP KECEPATAN LINEAR SEL BIOLOGIS
}

\author{
Nuri ${ }^{\left.1 a, 2 a^{*}\right)}$, Mahardika Prasetya Aji ${ }^{1 . b)}$, Sulhadi ${ }^{1 . c)}$ \\ 1) Prodi Pendidikan Fisik PPS UNNES, Gedung A Kampus Program Pasca Sarjana Unnes, \\ Bendan Ngisor Semarang 50233 \\ 2) SMK Tunas Harapan Pati, Jl. Raya Pati Trangkil km 4 Pati Jawa tengah. \\ ${ }^{*}$ Email : nuri.indramayu @ gmail.com
}

\begin{abstract}
ABSTRAK
Sel biologis merupakan kumpulan partikel yang bermuatan listrik. Jika sel biologis didekatkan dengan muatan listrik yang mengalir maka akan terpengaruh akibat adanya medan listrik dari muatan pada kabel penghantar. Hal ini dipicu adanya gaya interaksi antara muatan dalam inti sel dengan awan elektron yang menyelubunginya, terhadap medan listrik luar yang berasal dari aliran muatan kawat selenoid. Dalam kajian ini ditinjau secara mikroskopis pengaruh muatan listrik yang mengalir pada selenoid terhadap sel darah. Penelitian dilakukan pada setetes darah yang ditempatkan pada preparat microscop, di depan pereparat dipasang sebuah selenoida 1000lilitan dengan panjang 5cm, tegangan DC konstan 12volt dengan nilai kuat arus diubah-ubah. Dengan perbesaran 1000kali untuk memudahkan pengamatan, dibantu dengan camera digital yang terkoneksi langsung dengan laptop. Hasil yang didapatkan adalah dalam keadaan tanpa arus listrik sel darah diam, pada saat arus menaglir 0,05A-0,38A dihasilkan kecepatan dengan rentang nilai antara 11,11 pixel/sekon hingga 28,57pixel/sekon. Kesipuanya perubahan kuat arus pada selenoid berkorelasi positif terhadap kecepatan sel darah.
\end{abstract}

Kata kinci : Arus Dc, sel biologi, kecepatan linear, selenoid, dan sel darah

\section{Pendahuluan}

Demikian maraknya penggunan barang elektronik disekitar kita, sudah barang tentu menjadi faktor pengaruh kehidupan sehari-hari. Disadari atau tidak bahwa tubuh kita terdiri atas sel-sel biologis yang memiliki muatan yang memiliki gaya interaksi dengan medan listrik disekitarnya, terelpas dari menguntungkan atau tidak bagi tubuh, dalam kajian ini dibatasi pada ruang lingkup hubungan sebebakibat secara ilmiah dengan sekala mikro. Sel darah merupakan partikel bermuatan yang memiliki gaya interaksi dengan medan listrik disekitarnya. Sejauh mana pengaruh muatan listrk yang mengalir pada kawat terhadap kecepatan gerak linear sel darah itu sendiri akan kita ketahui pada percobaan ini.

\section{Metode Penelitian}

Dengan menggunakan sel darah manusia yang didekatkan pada sebuah selenoid berarus DC konstan. Variabel bebas adalah kuat arus listrik dari sebuah sumber tegangan 12 volt, dan selenoid 1000 lilitan, panjang selenoid $5 \mathrm{~cm}$, jarak sel $2 \mathrm{~cm}$ pada sisi tengah selenoid dan sebidang dengan kumparan bagian bawah, hal terebut merupakan variabel yang terkontrol. Dengan menggunakan bantuan microscop yang terhubung dengan camera digital. Sementara camera terkoneksi dengan layar laptop, tampilan diatur sedemikin hingga bayangan tampak jelas dan tapilan layar berukuran 800 X 600pixel. Perbesaran total microscop 100kali. Pencahayaan pada preparat menggunakan lampu.

Perhitungan kecepatan adalah hasil bagi jarak dan waktu tempuh. Jarak tempuh sel pada layar dengan satuan pixel, dan pewaktunya adalah durasi tayang pada video sel. Dalam rekaman didapatkan waktu sesuai yang kita inginkan.

Sumber masukan adalah generator DC, dengan rangkaian salah tegangan, agar nilai kuat arus yang mengalir lebih akurat. Perubahan nilai arus dilakukan dengan menggeser potensio meter.

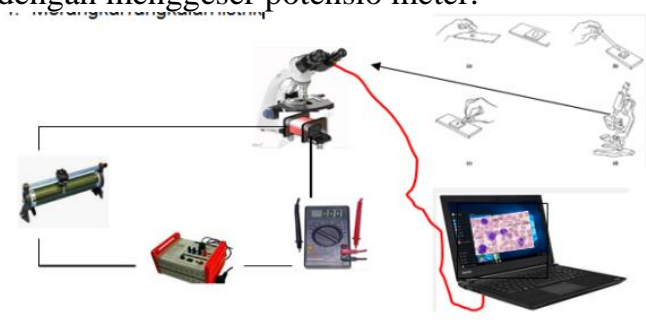

Gambar 1. Sekema percobaan 


\section{Hasil dan Pembahasan}

Hasil penelitian :

Tabel 1. Ttabel Pengematan.

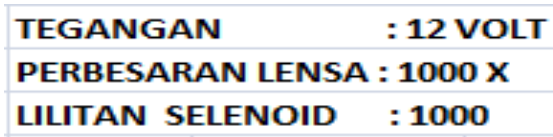

\begin{tabular}{|c|c|c|c|c|}
\hline NO & KUAT ARUS (A) & JARAK (PIXEL) & WAKTU (S) & KECEPATAN (PIXEL/S) \\
\hline $\mathbf{1}$ & $\mathbf{0}$ & $\mathbf{0}$ & $\mathbf{0}$ & $\mathbf{0}$ \\
\hline $\mathbf{2}$ & $\mathbf{0 , 0 5}$ & $\mathbf{2 0 0}$ & $\mathbf{1 8}$ & $\mathbf{1 1 . 1 1}$ \\
\hline 3 & 0,08 & 400 & 24 & $\mathbf{1 8 . 1 8}$ \\
\hline $\mathbf{4}$ & 0,12 & 600 & 28 & 21.43 \\
\hline $\mathbf{5}$ & 0,16 & 600 & 19 & 31.58 \\
\hline 6 & 0,20 & 600 & 25 & 24.00 \\
\hline $\mathbf{7}$ & 0,24 & 600 & 27 & 28.57 \\
\hline $\mathbf{8}$ & 0,28 & 600 & 21 & 18.75 \\
\hline 9 & 0,32 & 600 & 32 & 24.00 \\
\hline $\mathbf{1 0}$ & 0,36 & 600 & 25 & 28.57 \\
\hline $\mathbf{1 1}$ & 0,38 & 600 & 21 & 0,16 \\
\hline
\end{tabular}

Tabel 2. Grafik hubungan Kuat arus terhadap Kecepatan lienar sel

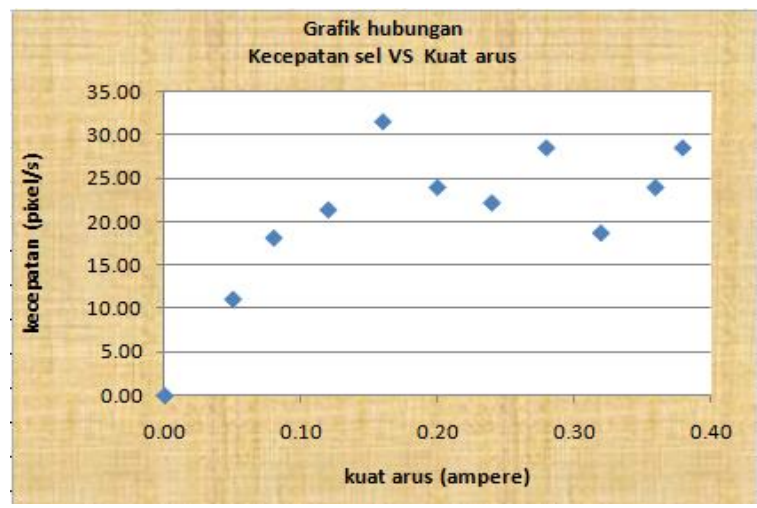

Hasil percobaan didapatkan grafik sumbu y sebagai variabel terikat yaitu kecepatan linear sel dalam (pixel/s), dan sumbu $x$ sebagai variabel bebeas yaitu kuat arus listrik dalam (ampere). Al hasil adalah perubahan kuat arus berpengaruh secara linier terhadap perubahan kecepatan gerak sel darah. dalam keadaan tanpa arus listrik sel darah diam, pada saat arus menaglir 0,05 A kecepatan sel $11,11 \mathrm{pixel} / \mathrm{sekon}$, pada arus $0,08 \mathrm{~A}$ kecepatan sel $18,18 \mathrm{pixel} /$ sekon, pada arus 0,12 kecepatan 21,43 pixel/sekon, pada arus 0,16 A kecepatan sel 31,58 pixel/sekon, pada arus 0,20 A kecepatan sel 24,00 pixel/sekon, pada arus 0,24 A kecepatan sel 22,22 pixel/sekon, pada arus 0,28 A kecepatan sel 28,57 pixel/sekon, pada arus 0,32 A kecepatan sel 18,75 pixel/sekon, pada arus 0,34 A kecepatan sel 24,00 pixel/sekon, pada arus 0,38 A kecepatan sel 28,57 pixel/sekon. Perubahan kecepatan pada tiga data pertama yakni $0,05 \mathrm{~A}$ hingga 0,16 A. terjadi akselerasi positif yang signifikan. Namun pada data selanjutnya yakni pada kuat arus 0,20 A hingga 0,38 A. kecepatan mengalami grafik saturasi, kecepatan linear sel dapat dianggap konstan.

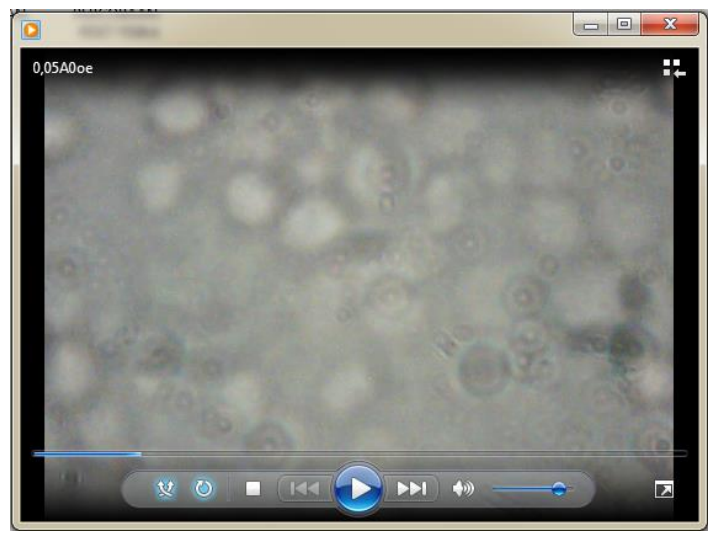

Gambar 2. Rekam gambar pada layar laptop

\section{Simpulan}

Dapat disimpulkan bahwa Kuat arus mempengaruhi kecepatan gerak linear sel darah dengan akselerasi yang tinggi pada awal pemberian arus, akibat pengaruh medan magnet yang cukup kuat (gerak siklotron), muatan bergerak searah medan magnet. Dan pada nilai kuat arus tertentu kecepatan sel mengalami saturasi atau bernilai konstan, hubungan perubahan arus dan kecepatan menerupai grafik steresis magnetisasi bahan. 


\section{Ucapan Terimakasih}

Penelitian ini terwujud berkat ridho Alloh SWT, serta dukungan keluarga, tidak lupa penulis ucapkan terimakasih kepada smk tunas harapan pati yang telah mengijinkan penelitian ini, terimakasih pada rekan-rekan mahasiswa PPS Unnes.

\section{Daftar Acuan}

[1] Ws Teerapt and Ph Phadungsak. Flow and heat transfer in biological tissue due to electromagnetic near-field explosure effects. Thailand (2015).

[2] Wiyanto. Elektromagnetika, yogyakarta, Graha ilmu (2008), p. 25-114

[3] Griffiths, D.J Introduction to Electrodynamics. Second Edition. New delhi : prentic-Hall of India Private Limited (1989), p. 44-281

[4] Nuri, "Pengeruh kuat arus DC pada selenoid terhadap kecepatan sel darah manusia, (2016).

[5] Rizka Ismatu, elektrorotasi sel telur lele semarang (2007)

[6] https://alkafyuone.wordpress.com dikutip 4 april 2016

[7] Evy Siscawati dalam Faktallmiah:2012 dikutip 5 april 2016 
